\title{
Uses of stable isotopes in clinical diagnosis and research in the paediatric population
}

\author{
O A F Bodamer, D Halliday
}

The landmark experiments of Schoenheimer and Rittenberg in the 1930 s provided the scientific foundation for the ensuing development and application of stable isotope techniques in clinical diagnosis and research. ${ }^{1}$

Stable isotopes are non-radioactive atoms of the same chemical element, which differ only in their number of neutrons. ${ }^{2}$ Many elements also have radioactive (non-stable) isotopes. Aspects of macronutrient metabolism have been investigated employing molecules labelled with ${ }^{2} \mathrm{H}$ (D or deuterium), ${ }^{13} \mathrm{C},{ }^{15} \mathrm{~N}$, and ${ }^{18} \mathrm{O}$. Extensive literature is available detailing the use of ${ }^{25} \mathrm{Mg}$, ${ }^{26} \mathrm{Mg},{ }^{42} \mathrm{Ca},{ }^{46} \mathrm{Ca},{ }^{48} \mathrm{Ca},{ }^{57} \mathrm{Fe},{ }^{58} \mathrm{Fe},{ }^{67} \mathrm{Zn}$, and ${ }^{70} \mathrm{Zn}$ isotopes in studies of mineral metabolism. The most commonly used radioactive isotopes are ${ }^{14} \mathrm{C}$ and ${ }^{3} \mathrm{H}$ (tritium). ${ }^{2}$ More than 6000 stable isotope labelled compounds (tracers) are commercially available for use in metabolic studies. Examples of some of these tracers are $\left[1-{ }^{13} \mathrm{C}\right]$ leucine, $\left[1-{ }^{13} \mathrm{C},{ }^{15} \mathrm{~N}\right]$ leucine, $\left[\mathrm{ring}-\mathrm{D}_{5}\right]$ phenylalanine, and $[6,6]-\mathrm{D}_{2}$ glucose. It is currently accepted that these compounds have negligible biological side effects, which renders them ethically acceptable for use in children. ${ }^{3}$

Following intravascular or oral administration, the tracer is metabolically indistinguishable from the equivalent unlabelled compound of interest (tracee). The metabolic fate of the compound can be assessed qualitatively and quantitatively by measuring the relative abundance of tracer and tracee and/or their respective metabolites with time. The detectable mass difference of tracer and tracee allows the analysis of compounds, extracted from plasma, by gas chromatography-mass spectrometry (GCMS, picogram sample size, analytical range 0.1-100 mole \%, precision \pm 0.2 mole $\%) .{ }^{4}$ The detection limit is considerably less than 0.1 mole $\%$, when tracers with multiple stable isotope labels (for example ring- $\mathrm{D}_{5}$ phenylalanine) are used. ${ }^{6}$ Stable isotopes in breath $\left({ }^{12} \mathrm{CO}_{2}\right.$ and $\left.{ }^{13} \mathrm{CO}_{2}\right)$ are analysed using an isotope ratio mass spectrometer (IRMS, microgram sample size, analytical range 0.0001-0.01 atom \% excess, precision \pm 0.0001 atom $\%{ }^{4}{ }^{7}$ Combustion IRMS has essentially the same analytical capabilities as IRMS but allows the combustion of tissue samples with subsequent analysis of gaseous isotope enrichment. ${ }^{4}$ Stable isotopes of minerals are typically analysed by thermal ionisation mass spectrometry (TIMS) or inductively coupled plasma mass spectrometry (ICP-MS) with high precision and sensitivity. $^{8}$

The advantages of stable isotope labelled compounds compared with their radioactive counterparts are many. Most importantly, several different stable isotope tracers can be safely administered simultaneously to the same subject without compromising future studies. The plasma volume which is needed from one sample to analyse the isotope enrichment is small, allowing even preterm infants to be studied. On average $0.5 \mathrm{ml}$ of plasma is needed for one study. The intramolecular location of one or more label(s) is determined easily, which allows the mapping of metabolic pathways. ${ }^{4}$ In contrast, no realistic radioactive tracers exist for certain chemical elements $\left(\mathrm{O}_{2}, \mathrm{~N}_{2}\right)$ and the handling, application, and disposal of radioactive tracers makes such studies hazardous to all participants. ${ }^{4}$

This review is written for (general) paediatricians to provide a concise and up to date overview of the use of stable isotope labelled compounds in clinical diagnosis and research in the paediatric population. For more detailed information on stable isotope models and additional applications the interested reader is referred to recently published reviews. ${ }^{4} 10$

\section{Breath tests}

With few exceptions stable isotope breath tests are based on the ingestion of substrates that are labelled with ${ }^{13} \mathrm{C}$ atoms. ${ }^{7}$ Following digestion and absorption, the substrates are metabolised and eventually oxidised to yield $\mathrm{H}_{2} \mathrm{O},{ }^{13} \mathrm{CO}_{2}$, and ${ }^{12} \mathrm{CO}_{2}$. Increased isotope enrichment in breath $\left({ }^{13} \mathrm{CO}_{2}\right)$ can be measured as outlined above and it is assumed that this increase indirectly reflects the intestinal absorption and metabolism of the substrate. The advantages are obvious. Breath tests are non-invasive and can be performed conveniently in an outpatient setting. The tracer is given orally and breath samples are subsequently collected. Breath tests do not provide metabolic information regarding pathways in which the substrate may play a role until it is finally oxidised. This may be of particular significance in patients with perturbed intermediary metabolism.

A complete description of all breath tests applied in the paediatric population is clearly beyond the scope of this review. A recently published Gut supplement presents an extensive series of papers reporting a wide range of diagnostic breath tests in children. ${ }^{11}$ However, we will exemplify the usefulness and clinical impact of stable isotope breath tests in several relevant clinical areas.

Depending on the type of tracer, the isotope enrichment in breath is an indirect reflection of gastrointestinal and/or liver function. The most commonly used substrates in this context are trioctanoin, triolein, octanoic acid, aminopyrine, and caffeine respectively. ${ }^{712} 13$

The ${ }^{13} \mathrm{C}$ urea breath test exemplifies a stable isotope breath test which is used for the diagnosis and management of Helicobacter 
pylori associated gastrointestinal disease in the paediatric population. ${ }^{7} \mathrm{H}$ pylori synthesises and secretes significant amounts of urease, an enzyme that catalyses the oxidation of urea to $\mathrm{NH}_{3}$ and $\mathrm{CO}_{2}$. Consequently, oral administration of ${ }^{13} \mathrm{C}$-urea will lead to increased excretion of ${ }^{13} \mathrm{CO}_{2}$ in a child with $\mathrm{H}$ pylori associated gastrointestinal disease. ${ }^{7}$ This stable isotope breath test is very sensitive and allows the reliable identification of $H$ pylori with only two breath samples following an oral bolus of ${ }^{13} \mathrm{C}$-urea. ${ }^{14}$

\section{Body composition and energy expenditure}

From a clinical standpoint, accurate measurement of total body water can provide indirect information relating to whole body composition and energy balance. The mechanisms of energy balance control are unclear and the study of this balance is complicated by the fact that alterations in body weight may reflect a change in energy stores, an alteration in total body water, or both.

Total body water can be calculated by employing standard isotope dilution techniques. Knowledge of the "fixed" water content of the fat free mass permits calculation of this body compartment. Subtraction of this mass from body weight provides indirectly the mass of body fat. Both ${ }^{2} \mathrm{H}_{2} \mathrm{O}$ and $\mathrm{H}_{2}{ }^{18} \mathrm{O}$ have been used to estimate total body water in renal insufficiency, cystic fibrosis, malnutrition, and in endocrine disorders. ${ }^{15-19}$

The doubly labelled water method (employing ${ }^{2} \mathrm{H}_{2} \mathrm{O}$ and $\mathrm{H}_{2}{ }^{18} \mathrm{O}$ ) has become established, over the past 20 years, as the only method currently available for measuring total energy expenditure in completely free living subjects. ${ }^{20}$ Following isotope administration and equilibration, isotopically labelled hydrogen will leave the body as water (urine plus evaporative losses), whereas isotopically labelled oxygen will leave the body both as water and as carbon dioxide (action of carbonic anhydrase). Monitoring the individual enrichment decay curves for these two isotopes over 7-14 days will result in different slopes. The difference in slopes is directly proportional to total body carbon dioxide production. This direct estimate of metabolic rate can then be converted to units of heat production by incorporating knowledge or estimates of the chemical composition of the foodstuffs being oxidised. This influences the energy equivalence of each litre of carbon dioxide produced.

The method has been validated in infants. ${ }^{21}{ }^{22}$ Application of the method to determine energy expenditure in small for gestational age infants, and growth and development in normal infancy and in malnourished children have been reported. ${ }^{23-25}$ Published data relating to energy expenditure in short and normal stature Guatemalan children and obese and non-obese adolescents (12-18 years) are available. $^{26} 27$

\section{Inborn errors of metabolism}

Inborn errors of metabolism are ideal study areas for the use of stable isotopes. Many biochemical pathways have intermediary compounds of which stable isotopes are available, representing different enzymatic activities. Consequently children with inborn errors of metabolism were among the first to be studied with stable isotopes. ${ }^{28} 29$

Stable isotope breath tests were used in inborn errors of metabolism for non-invasive diagnosis and reliable semiquantitative estimation of whole body enzyme capacity in subjects with galactosaemia and maple syrup urine disease. ${ }^{30-33}$ Response to therapeutic intervention and genotype-phenotype correlations were assessed in children with thiamine responsive maple syrup urine disease ${ }^{34}$ and galactosaemia, respectively. ${ }^{30}$

Stable isotope studies involving infusions of tracer and blood sampling have been undertaken in many different inborn errors of metabolism, including glycogen storage diseases, ${ }^{35-37}$ galactosaemia, ${ }^{30}$ phenylketonuria (PKU), ${ }^{38}{ }^{39}$ organic acidurias, ${ }^{33}$ and urea cycle defects. ${ }^{40}{ }^{41}$ Thompson et al have shown that phenylalanine or propionate are metabolised in children with PKU or certain organic acidurias (methylmalonic aciduria and propionic aciduria), respectively. ${ }^{33}$

Significant phenylalanine hydroxylation in children with classical PKU was recently contradicted by van Spronsen et al who showed clearly reduced (whole body) enzyme activities when compared with normal healthy control subjects. ${ }^{39}$ They also concluded that dietary phenylalanine tolerance did not correlate with in vivo hydroxylation of phenylalanine, an important finding which increases the significance of adequate substrate disposal (for protein synthesis).

\section{Macronutrient metabolism}

Protein, lipid, and glucose kinetics in infants and children have been measured using a range of labelled substrates: $\left[1-{ }^{13} \mathrm{C}\right]$ leucine and $\left[\mathrm{D}_{5}\right]$ phenylalanine; $\left[{ }^{13} \mathrm{C}\right]$ labelled glycerol, palmitic or linoleic acids; and $\left[{ }^{13} \mathrm{C}\right]$ glucose respectively.

van Goudoever et al studied protein kinetics in two groups of preterm infants. ${ }^{42}$ The first group was supplemented with amino acids while the second group received only glucose infusions. Nitrogen and leucine balance improved significantly in the first group, secondary to increased protein synthesis and decreased protein breakdown, a clear indication of the benefits of early administration of amino acids in preterm infants. These findings confirmed earlier published results. ${ }^{43-45}$ More recently Clark et al investigated the effects of parenteral nutrition on leucine and phenylalanine kinetics in preterm infants and showed an acute increase in whole body protein synthesis as well as a reduction in protein breakdown. ${ }^{46} \mathrm{~A}$ comparison of whole body protein turnover in appropriate for gestational age and small for gestational age infants using two labelled amino acids gave encouragingly similar quantitative results. ${ }^{47}$

Nitrogen balance and protein turnover have been investigated during growth failure in low birthweight infants, ${ }^{48}$ and in sick premature neonates during the first few days of life. ${ }^{49}$ 
Phenylalanine hydroxylase status was investigated in sick preterm neonates with respiratory distress syndrome..$^{50}$ The results obtained in this study did not support the hypothesis that the enzyme activity was low in these preterm infants.

Albumin synthetic rate has been measured in premature infants and in oedematous and non-oedematous protein energy malnourished children..$^{51}{ }^{52}$ In the first study it was found that both the fractional and absolute synthetic rate for albumin in the infants were much higher than rates found in young adults. The results from the latter study suggested that repletion of the albumin pool of children with protein energy malnutrition was not mediated by changes in the fractional synthetic rate. Additionally it was shown that the oedema of malnutrition was not solely a result of the hyperalbuminaemia.

Whole body protein metabolism has been measured in children with cancer using both labelled leucine and phenylalanine. ${ }^{53}$ Both tracers gave similar results which indicated that both the rates of synthesis and breakdown were higher than in normal children. The effects of feeding on protein turnover in children with cystic fibrosis and healthy controls have been compared. ${ }^{54}$ From their results the authors suggest that feeding may affect protein turnover differently in children with cystic fibrosis when compared with control children. It was suggested that the differences might be independent of plasma insulin concentration.

Studies of plasma arginine and leucine kinetics in paediatric burns patients suggested that the former amino acid was conditionally indispensable in terms of maintaining protein homoeostasis in severely burned children. ${ }^{55}$ In healthy children recovering from burn injury, rates of whole body protein synthesis in relation to basal energy expenditure have been explored. ${ }^{56}$ Perhaps surprisingly it has been shown that infants and children do not increase whole body protein turnover or metabolic rate after major operations. ${ }^{57}$ Respiratory quotient fell during the operative period, reflecting mobilisation of endogenous fat. It was speculated that the lack of catabolism observed in these subjects was a result of the switching of protein synthesis from growth to tissue repair. Other studies have looked at amino acid and protein metabolism in critically ill children. ${ }^{58} 59$

A significant early study quantitating palmitate and glycerol turnover and the contribution of glycerol to neonatal hepatic glucose output showed the potential of stable isotopes in studies of lipid metabolism. ${ }^{60}$

It has long been speculated that premature infants who are fed formulas that are low in long chain polyunsaturated fatty acids (LCP) have low plasma LCP levels as a result of immature biosynthetic pathways. Carnielli et al addressed this issue in an elegant study. ${ }^{61}$ They gave five preterm infants formula mixed with $\left[{ }^{13} \mathrm{C}\right]$ linoleic and linolenic acids (both unsaturated C18 fatty acids) and showed a significant increase in ${ }^{13} \mathrm{C}$ enrichment in LCP derivatives originating from the $\mathrm{C} 18$ precursors. Selective release of fatty acids from lipolysis such as the release of palmitic or linoleic acids may play an important role in the overall response to critical illness. ${ }^{62}$ The rate of appearance of $\left[\mathrm{U}-{ }^{13} \mathrm{C}\right]$ linoleic acid was significantly greater than that of $\left[\mathrm{U}^{13} \mathrm{C}\right]$ palmitic acid when measured in critically ill infants. However, it is not clear whether a selective release of fatty acids may also be present in healthy infants.

Fatty acid oxidation was studied in 12 patients (3-19 years) with seizure disorders, who were receiving valproic acid, predominantly as monotherapy, before and following L-carnitine supplementation. ${ }^{63}$ Results suggested that, in patients at low risk of valproic acid induced hepatotoxicity, the acid caused metabolic abnormalities that resembled those observed in inborn errors of mitochondrial beta oxidation that were not corrected by the L-carnitine supplementation.

The mechanisms controlling fat intake and fat oxidation are poorly understood. A recent study looked at fat oxidation and adiposity in prepubertal children. ${ }^{64}$ Using a combination of the ingestion of $\left[{ }^{13} \mathrm{C}\right]$ labelled mixed fatty acids (in an ice cream meal) and indirect calorimetry permitted the partitioning of exogenous and endogenous resting fat oxidation rate over a nine hour postprandial period. Exogenous and endogenous fat oxidation, expressed as a proportion of total fat oxidation, was directly related to and inversely related to fat mass respectively. It was suggested that the enhanced exogenous fat oxidation with increasing adiposity in the dynamic phase of obesity may represent a protective mechanism. This would act to prevent further increase in the fat mass and maintain fat oxidation at such a level when the body ingests a large amount of dietary fat, as is often encountered in obese children.

Quantitation of various aspects of glucose kinetics can be achieved using several available glucose tracers: $\left[6,6{ }^{2} \mathrm{H}_{2}\right],\left[1-{ }^{13} \mathrm{C}\right]$, or $\left[\mathrm{U}-{ }^{13} \mathrm{C}\right]$ glucose. ${ }^{65}$ Gluconeogenesis from lactate has been described in fasting infants using a sophisticated protocol. ${ }^{66}$ In this study $54 \%$ of glucose was found to be derived from plasma lactate. Gluconeogenesis in the fetus and neonate has recently been described in depth. ${ }^{67}$ Very low birthweight infants (less than $1100 \mathrm{~g}$ ) have been studied with respect to endogenous glucose production and disappearance. ${ }^{68}$ It was shown that these very low birthweight infants utilise some three to four times more glucose per kilogram body weight than adults. This presumably reflects their high ratio of brain to body weight. Endogenous glucose production provided only about $30 \%$ of the glucose needed by these infants; the authors suggested this fact provided a mandate for the exogenous infusion of glucose to prevent hypoglycaemia developing.

\section{Mineral metabolism}

Studies employing stable isotopes of zinc, iron, calcium, and/or magnesium have been performed to assess absorption, bioavailability, or balance of these minerals in healthy children or children with disorders affecting the gastrointestinal tract. ${ }^{69-73}$ Both intrinsic and extrinsic labelling techniques have been employed in these studies. The latter technique is far less 
expensive in that the isotope is simply mixed with the food before consumption. In this instance it has to be assumed that the extrinsic label equilibrates completely with the native intrinsic inorganic element in the diet, and is absorbed and metabolised in an identical fashion. Plant and animal foods can be labelled intrinsically by the incorporation of the chosen isotope biosynthetically into the growing food. Several procedures to achieve this end have been described. ${ }^{74}{ }^{75}$ When calcium and magnesium metabolism was assessed in prepubertal and pubertal girls and boys, Abrams et al showed that total calcium absorption from milk was increased in pubertal compared to prepubertal children. ${ }^{72}$ Almost $50 \%$ of the children studied had negative magnesium balances despite magnesium intakes based on the recommended dietary allowance for magnesium. A more detailed review relating to stable isotopes and mineral metabolism in children was recently published. ${ }^{76}$

\section{Conclusion}

Stable isotopes are ideal "tools" for the dynamic assessment of in vivo metabolism in the paediatric population. Not only are these tracers safe and therefore ethically justifiable, in addition they may be particularly important for the validation of new treatment modalities, such as novel drug treatment or gene therapy. Many more exciting studies are currently underway to enhance our knowledge of paediatric metabolism and (patho)physiology, an important factor for the continued reduction of paediatric morbidity and mortality.

1 Schoenheimer R, Rittenberg D. Deuterium as an indicator in the study of intermediary metabolism. 7 Biol Chem 1935;111:175-81.

2 Wolfe RR. Basic characteristics of isotopic tracers. In: Wolfe $\mathrm{RR}$, ed. Radioactive and stable isotope tracers in biomedicine. Principles and practice of kinetic analysis. New York: Wiley-Liss, 1992:1-17.

3 Jones PJH, Leatherdale ST. Stable isotopes in clinical research: safety reaffirmed. Clin Sci 1991;80:277-80.

4 Bier D. Stable isotopes in biosciences, their measurement and models for amino acid metabolism. Eur 7 Pediatr 1997; 156(suppl 1):S2-8.

5 Patterson BW, Zhao G, Klein S. Improved accuracy and precision of gas chromatograph/mass spectrometry measurements for metabolic tracers. Metabolism 1998;47:70612.

6 Calder AG, Anderson SE, Grant I, et al. The determination of low d5phenylalanine enrichment (0.002-0.09 atom percent excess), after conversion to phenylethylamine, in relation to protein turnover studies by gas chromatography/ electron ionization mass spectrometry. Rapid Commun Mass Spectrom 1992:6:421-4.

7 Weaver LT. Stable isotope breath tests. Nutrition 1998;14: $826-9$

8 Crews HM, Ducros V, Eagles J, et al. Mass spectrometric methods for studying nutrient mineral and trace element absorption and metabolism in humans using stable absorption and metabolism in

9 Pacy PJ, Cheng KN, Thompson GN, Halliday D. Stable isotopes as tracers in clinical research. Ann Nutr Metab 1989;33:65-78

10 Thompson GN, Pacy PJ, Ford GC, Halliday D. Practical considerations in the use of stable isotope labelled compounds as tracers in clinical studies. Biomed Environ Mass Spectrom 1989;18:321-7.

11 Harding M, Coward WA, eds. Application of stable isotopes in clinical medicine. Gut 1998;43(suppl 3).

12 Schneider JF, Schoeller DA, Nemchausky B, et al. Validation of ${ }^{13} \mathrm{CO}_{2}$ breath analysis as a measurement of demethylation of stable isotope labeled aminopyrine in man. Clin Chim Acta 1978;84:153-62.

13 Pons G, Blais J-C, Rey E, et al. Maturation of caffeine N-demethylation in infancy: a study using the ${ }^{13} \mathrm{CO}_{2}$ breath test. Pediatr Res 1988;23:632-6.

14 Roland M, Lambert I, Gormally S, et al. Carbon 13-labeled urea breath test for the diagnosis of Helicobacter pylori infection in children. $\mathcal{F}$ Pediatr 1997;131:815-20.
15 Bradbury MG, Brocklebank JT, Smye SW, Davies PS. Total body water measurement in renal insufficiency. Pediatr Nephrol 1996;10:195-9.

16 de Meer K, Gulmans VA, Westerterp KR, et al. Skinfold measurements in children with cystic fibrosis: monitoring fat-free mass and exercise effects. Eur $\mathcal{F}$ Pediatr 1999;158: $800-6$.

17 Stettler N, Kawachak DA, Boyle LL, et al. A prospective study of body composition changes in children with cystic fibrosis. Ann N Y Acad Sci 2000;904:406-9.

18 Fjeld CR, Freundt-Thurne J, Schoeller DA. Total body water measure by $18-\mathrm{O}$ dilution and bioelectrical impedance in well and malnourished children. Pediatr Res 1990;27:98-102.

19 Suprasongsin C, Kalhan S, Arslanian S. Determination of body composition in children and adolescents: validation of bioelectrical impedance with isotope dilution technique. $\mathcal{F}$ Pediatr Endocrinol Metab 1995;8:103-9.

20 Schoeller DA, van Santen E. Measurement of energy expenditure in humans by doubly labeled water method. $f$ Appl Physiol 1982;53:955-9.

21 Roberts SB, Coward WA, Schlingenseipen K-H, et al. Comparison of the doubly-labelled water $\left({ }^{2} \mathrm{H}_{2} \mathrm{O}-\mathrm{H}_{2}{ }^{18} \mathrm{O}\right)$ method with indirect calorimetry and a nutrient-balance study for simultaneous determinations of energy expenditure, water intake and metabolisable energy intake in pre-term infants. Am F Clin Nutr 1986;44:315-22.

22 Jones PJ, Winthrop AL, Schoeller DA, et al. Validation of doubly labeled water for assessing energy expenditure in infants. Pediatr Res 1987;21:242-6.

23 Davies PSW, Clough H, Bishop NJ, et al. Total energy expenditure in small for gestational age infants. Arch Dis Child Fetal Neonatal Ed 1996;75:F46-8.

24 Davies PSW. Energy requirements for growth and development in infancy. Am 7 Clin Nutr 1998;68:939S-43S.

25 Fjeld CJ, Schoeller DA, Brown KH. Energy expenditure of malnourished children during catch-up growth. Proc Nutr Soc 1988;47:227-31.

26 Wren RE, Blume H, Mazariegos M, et al. Body composition, resting metabolic rate, and energy requirements of short- and normal-stature, low income Guatemalan children. Am f Clin Nutr 1997;66:406-12.

27 Bandini LG, Schoeller DA, Cyr HN, Dietz WH. Validity of reported energy intake in obese and nonobese adolescents. Am f Clin Nutr 1990;52:421-5.

28 Nicholson JF, Freeman JM. Metabolism of compounds labeled with $15 \mathrm{~N}$ by an infant with congenital hyperammonemia. Pediatr Res 1972;6:252-60.

29 Crane CW, Jenner FA, Pollit RJ. The relationship between the formation of urea and argininosuccinate in a patient with argininosuccinic aciduria studied with labelled precursors. Clin Sci Mol Med 1974;46:715-27.

30 Berry GT, Nissim I, Gibson JB, et al. Quantitative measurement of whole body galactose metabolism in galactosemic patients. Eur $\mathcal{F}$ Pediatr 1997; 156(suppl 1):S43-9.

31 Schadewaldt P, Bodner A, Brosicke H, et al. Assessment of whole body L-leucine oxidation by noninvasive L-[113C]leucine breath tests: a reappraisal in patients with maple syrup urine disease, obligate heterozygotes, and healthy subjects. Pediatr Res 1998;43:592-600.

32 Thompson GN, Francis DE, Halliday D. Acute illness in maple syrup urine disease: dynamics of protein metabolism and implications for management. F Pediatr 1991;119:35-

33 Thompson GN, Walter JH, Leonard JV, Halliday D. In vivo enzyme activity in inborn errors of metabolism. Metabolism 1990;8:799-807.

34 Ellerine NP, Herring WJ, Elsas LJ, et al. Thiamin-responsive maple syrup urine disease in a patient antigenically missing dihydrolipoamide acyltransferase. Biochem Med Metab Biol 1993;49:363-74.

35 Kalderon B, Korman SH, Gutman A, Lapidot A. Glucose recycling and production in glycogenosis type I and III: stable isotope technique study. Am f Physiol 1989;257: E346-53.

36 Lapidot A. Inherited disorders of carbohydrate metabolism in children studied by 13C-labelled precursors, NMR and GC-MS. F Inherit Metab Dis 1990;13:466-75.

37 Bodamer OAF, Mayatepek E, Leonard JV. Leucine and glucose kinetics in glycogen storage disease type IIIa. F Inherit Metab Dis 1997;20:847.

38 Thompson GN, Halliday D. In vivo phenylalanine hydroxylation in phenylketonuria. Significant phenylalanine hydroxylation in vivo in patients with classical phenylketonudroxylation in vivo in patients with

39 van Spronsen FJ, Reijngoud DJ, Smit GP, et al. Phenylketonuria. The in vivo hydroxylation rate of phenylalanine into tyrosine is decreased. $\mathcal{F}$ Clin Invest 1998;101:2875-80.

40 Yudkoff M, Daikhin Y, Nissim I, et al. In vivo nitrogen metabolism in ornithine transcarbamylase deficiency. $f$ Clin Invest 1996;98:2167-73.

41 Lee B, Yu H, Jahoor F, et al. In vivo urea cycle flux distinguishes and correlates with phenotypic severity in disorders of the urea cycle. Proc Natl Acad Sci U S A 2000; 97:8021-6.

42 van Goudoever JB, Colen T, Wattimena DJL, et al. Immediate commencement of amino acid supplementation in preterm infants: effect on serum amino acid concentrations and protein kinetics on the first day of life. $\mathcal{F}$ Pediatr 1995; 127:458-65.

43 Mitton SG, Garlick PJ. Changes in protein turnover after the introduction of parenteral nutrition in premature amino acid solutions. Pediatr Res 1992;32:447-54. 
44 van Lingen RA, van Goudoever JB, Luijendijk IHT, et al. Effects of early amino acid administration during total parenteral nutrition on protein
infants. Clin Sci 1992;82:199-203.

45 Rivera A, Bell EF, Bier DM. Effect of intravenous amino acids on protein metabolism of preterm infants during the first three days of life. Pediatr Res 1993;33:106-11.

46 Clark SE, Karn CA, Ahlrichs JA, et al. Acute changes in leucine and phenylalanine kinetics produced by parenteral nutrition in premature infants. Pediatr Res 1997;41:568-74

47 van Goudoever JB, Sulkers EJ, Halliday D, et al. Whole body protein turnover in preterm appropriate for gestational age and small for gestational age infants: comparison of [15N] glycine and $[1-13 \mathrm{C}]$ leucine administered simultaneously. Pediatr Res 1995;37:381-8.

48 Kandil H, Darwish O, Hammad S, et al. Nitrogen balance and protein turnover during the growth failure in newly born low-birth-weight infants. Am f Clin Nutr 1991;53: born low- $1411-17$.

49 Mitton SG, Calder AG, Garlick PJ. Protein turnover rates in sick, premature neonates during the first few days of life. Pediatr Res 1991;30:418-22.

50 Shortland GJ, Walter JH, Fleming PJ, Halliday D. Phenylalanine kinetics in sick preterm neonates with respiratory distress syndrome. Pediatr Res 1994;36:713-18.

51 Yudkoff M, Nissim I, McNellis W, Polin R. Albumin synthesis in premature infants: determination of turnover with $[15 \mathrm{~N}]$ glycine. Pediatr Res 1987;21:49-53.

52 Morlese JF, Forrester T, Badaloo A, et al. Albumin kinetics in edematous and nonedematous protein-energy malnourished children. Am f Clin Nutr 1996;64:952-9.

53 Daley SE, Pearson AD, Craft AW, et al. Whole body protein metabolism in children with cancer. Arch Dis Child $1996 ; 75 \cdot 273-81$.

54 Kien CL, Zipf WB, Horswill CA, et al. Effects of feeding on protein turnover in healthy children and in children with cystic fibrosis. Am f Clin Nutr 1996;64:608-14.

55 Yu Y-M, Sheridan RL, Burke JF, et al. Kinetics of plasma arginine and leucine in pediatric burn patients. Am $\mathcal{f}$ Clin Nutr 1996;64:60-6.

56 Kien CL, Rohrbaugh DK, Burke JF, Young VR. Whole body protein synthesis in relation to basal energy expenditure in healthy children recovering from burn injury. Pediatr Re 1978;12:211-16

57 Powis MR, Smith K, Rennie M, et al. Effect of major abdominal operations on energy and protein metabolism in infants and children. F Pediatr Surg 1998;33:49-53.

58 Bodamer OAF, Leonard JV, Tasker RC, et al. Protein turnover in critically ill children. Eur F Pediatr 1997;156(supp 1):S59-61.

59 Castillo L, Yu Y-M, Marchini JS, et al. Phenylalanine and tyrosine kinetics in critically children with sepsis. Pediat Res 1994;35:580-4.
60 Bougneres PF, Karl IE, Hillman LS, Bier DM. Lipid transport in the human newborn. Palmitate and glycerol turnoer and the contribution of glycerol to neonatal hepatic glucose output. $\mathcal{F}$ Clin Invest 1982;70:262-70.

61 Carnielli VP, Wattimena DJL, Luijendijk IHT, et al. The very low birth weight premature infant is capable of synthesizing arachidonic and docosahexaenoic acids from linoleic and linolenic acids. Pediatr Res 1996;40:169-74.

62 Cogo PE, Giordano G, Badon $\mathrm{T}$, et al. Simultaneous measurement of the rates of appearance of palmitic and linoleic acid in critically ill infants. Pediatr Res 1997;41: $178-82$

63 Kossak BS, Schmidt-Sommerfeld E, Schoeller DA, et al. Impaired fatty acid oxidation in children on valproic acid and the effect of L-carnitine. Neurology 1993;43:2362-8.

64 Maffeis C, Armellini F, Tato L, Schutz Y. Fat oxidation and adiposity in prepubertal children: exogenous versus endog-

65 Kalhan SC. Stable isotope tracers for studies of glucose metabolism. F Lab Clin Med 1990;116:615-22.

66 Bougneres PF, Rocchiccioli F, Nurjhan N, Zeller J. Stable isotope determination of plasma lactate conversion into clucose in fasting infants. Am 7 Physiol 1995;268:E652-9.

67 Kalhan S, Parimi P. Gluconeogenesis in the fetus and neonate. Semin Perinatol 2000;24:94-106.

68 Tyrala EE, Chen X, Boden G. Glucose metabolism in the infant weighing less than 1100 grams. F Pediatr 1994;125: $283-7$.

69 Serfass RE, Ziegler EE, Edwards BB, Houk RS. Intrinsic and extrinsic stable isotopic zinc absorption by infants from formulas. $\mathcal{F}$ Nutr 1989;119:1661-9.

70 Hambidge KM, Krebs NF, Miller L. Evaluation of zinc metabolism with use of stable isotope techniques: implications for the assessment of zinc status. Am $\mathcal{F}$ Clin Nutr 1998;68(suppl):410S-13S

71 Davidsson L, Galan P, Cherouvrier F, et al. Bioavailability in infants of iron from infant cereals: effects of dephytinization. Am 7 Clin Nutr 1997;65:916-20.

72 Abrams SA, Grusak MA, Stuff J, O'Brien KO. Calcium and magnesium balance in 9-14-y-old children. Am 7 Clin Nutr 1997;66:1172-7.

73 Bronner F, Abrams SA. Development and regulation of calcium metabolism in healthy girls. F Nutr 1998;128:147480

74 Fox T, Fairweather-Tait SJ, Eagles J, Wharf SG. Intrinsic labelling of different foods with stable isotope of zinc $\left({ }^{67} \mathrm{Zn}\right)$ for use in bioavailability studies. Br F Nutr 1991;66:57-63.

5 Weaver CM, Heaney RO, Martin BR, Fitzsimmons ML Extrinsic vs intrinsic labelling of the calcium in whole wheat flour. Am f Clin Nutr 1992;55:452-4.

76 Abrams SA. Using stable isotopes to assess mineral absorption and utilization by children. Am $\mathcal{F}$ Clin Nutr 1999;70:955-64.

\section{FETAL AND NEONATAL EDITION}

\section{May 2001 issue}

The following articles-being published in the May 2001 issue of the Fetal and Neonatal edition of the Archives of Disease in Childhood - may be of general interest to paediatricians.

LEADING ARTICLES

Management of the neonate with symptomatic congenital heart disease

D F Penny, L S Shekerdemian

ORIGINAL ARTICLES

Community based universal neonatal hearing screening by health visitors using otoacoustic emissions

$M$ Owen, $M$ Webb, K Evans

\section{REVIEWS}

Hepatitis $\mathbf{C}$ in pregnancy

Y Nako, A Tachibana, T Fujiu, T Tomomasa, A Morikawa 